\title{
RECENT LEGISLATIVE DEVELOPMENTS: ENGLAND
}

\author{
B. J. T. HANSON \\ Registrar and Legal Adviser to the General Synod
}

This report covers two Groups of Sessions, namely the July 1995 Sessions which were the last of the 1990-1995 Synod and the November 1995 Sessions following the Inauguration of the 1995-2000 Synod by Her Majesty the Queen.

At the July 1995 Sessions, the Royal Licence having been obtained, Amending Canon No 18 was promulged. The Canon made minor amendments to Canons $\mathrm{H}$ 2 and $\mathrm{H} 3$ concerning membership of the Upper and Lower Houses of the Convocations. The amendments were needed prior to the elections held in July to October of this year.

The General Synod also approved amendments to the Constitution of the Diocese in Europe proposed by the Diocesan Bishop and the usual Fees Orders under the Ecclesiastical Fees Measure 1986. The Synod was then dissolved until the inauguration in November.

At the November Sessions the Lay Office-Holders Measure was generally approved as was Amending Canon No 20 which will make amendments to the Canon Law as a result of the passing of the draft Measure. The draft Measure would repeal and replace the Churchwardens (Appointment and Resignation) Measure 1964. It is proposed that those to be appointed churchwardens should be actual communicants (as defined in the Church Representation Rules), have his or her name on the electoral roll and not be a churchwarden in any other parish. It is also proposed that there should be a mandatory retirement age for churchwardens and that a warden should not serve continuously for more than six years, with a break of not less than two years before the next period of service. The prohibition on aliens and Jews from serving is to be abolished. The draft legislation also provides for nominations for the office of churchwarden to be made before the annual meeting and a written consent to serve from candidates will be required. It is proposed that the 'meeting of parishioners' should continue to choose the churchwardens and there will be new provisions concerning admission to office and the visitation.

The ELS submitted a memorandum to the Working Party having responsibility for producing the Measure (see (1994) 3 Ecc. LJ 354) and a number of points made in that memorandum have been incorporated into the draft legislation. The Measure and Canon now go to a Revision Committee and Synod members have the right to submit proposals for amendment.

Also at the November Sessions, Amending Canon No 19 was promulged. This amends a number of canons following the Royal Assent of the Church of England (Miscellaneous Provisions) Measure 1995 (see (1994) 3 Ecc. LJ 191). The General Synod also approved the Church Representation Rules (Amendment) Resolution 1995 which makes provision for independent examiners and auditors of PCC financial statements as required by the Charities Act 1993 and for modifications to the Rules concerning provincial episcopal visitors appointed under the Episcopal Ministry Act of Synod 1993. 